\title{
The relationship between customer satisfaction, social responsibility, and long-run financial performance
}

\author{
Y-CWANG, ${ }^{1} B-P$ VENTER, ${ }^{2}$ AND C-H HUANG ${ }^{3}$
}

\begin{abstract}
This paper investigates the link between long-run corporate financial performance, corporate social responsibility, and customer satisfaction. Using annual financial data, customer satisfaction index, and the Dow Jones Sustainability Index, the paper seeks to establish whether it pays organizations to use ethical methods in striving to be sustainable. Data used for this research cover the period 2001 to 2008. We used dynamic panel data linear regression models to analyze the effect of customer satisfaction and social responsibility on short-run and long-run financial performance. It was found that it may benefit organizations to use ethical methods in pursuing sustainability. since organizations who invest time, money, and effort in corporate social responsibility activities, their good reputations and satisfied customers yield long-term cash flow growth.
\end{abstract}

Keywords: corporate customer satisfaction, Corporate Social Responsibility, corporate financial performance.

Disciplines: business studies, international studies, ethics, finance studies.

\section{Introduction}

Corporate social responsibility (CSR) is enjoying renewed interest from business managers and executives, marketers, and public relations practitioners, who seem to recognize the value of investing time, money, and effort in CSR while at the same time seeming unable to quantify the contribution of CSR to the organizational bottom line. Porter \& Kramer (2006) make the points that CSR is a fragmented practice, and seldom coordinated with other organizational functions. They argue that CSR should be connected not only to the society it serves, but also the organization's strategy and tactical activities. They are of the firm opinion that investing time, money, and effort in CSR activities would be of benefit to the organization.

Wigley (2009) connects CSR not only to society and organizational activities, but also specifically to customers, when she asks whether increased awareness of CSR activity

1. Yi-Chen Wang, National Kaohsiung First University of Science and Technology, Taiwan. Email: yiwang@ccms.nkfust.edu.tw.

${ }^{2}$. Ben-Piet Venter, Beijing Foreign Studies University, Beijing, China. Email: benpiet@hotmail.com.

${ }^{3}$. Chia-Hsing Huang, SolBridge International School of Business, South Korea. Email: koreasing@solbridge.ac.kr. 
"make[s] cents?" The results of her study indicate that consumers would be more willing to purchase products if they were more aware of the CSR activities of organizations. Against the backdrop of a world economic crisis, signs are becoming more prevalent that organizations facing ruin have been chasing short term profits and not long-term sustainability - an unethical practice at best, and bad public relations at worst. For many years, public relations practitioners and lately responsible business managers have called for business to be more socially responsible. However, their attempts have met with mixed success, perhaps in part because organizational goodwill activities such as CSR projects have not been firmly connected to other organizational activities as Porter \& Kramer (2006) claim.

Three traditional areas of business-customer interface may be identified as marketing, public relations, and finance. The task of marketing is to seek, find, attract, satisfy, and retain customers. To marketing, customer satisfaction is important. The task of public relations is to build and maintain mutually beneficial relationships between the organization and a variety of stakeholder groups such as shareholders, customers, suppliers, and so on. Typically, financial management has the job of ensuring that the organization's income and expenditure is managed in such a way that the organization maximizes profit (firm value) for shareholders. In keeping with stakeholder management theories, the organization engages in corporate social responsibility programs to illustrate its commitment to the interests of all stakeholders. However, these goals (profit maximization, customer satisfaction, and social responsibility) could easily become mutually exclusive, and one practiced to the detriment of another.

Is this necessarily the case that one should be viewed as exclusive to the other, or is there empirical evidence to suggest that financial performance, customer satisfaction, and focus on corporate social responsibility can work in harmony to the benefit of the organization? Is it really the case that shareholder profit will have a negative effect on social investment? Is customer satisfaction more important than profit? Or is there a link between these phenomena? Is it possible that satisfied customers and non-financial stakeholders can benefit the organization's shareholders and its sustainability in the long run? This paper seeks to establish whether such a link exists. In other words, can and should finance, marketing, and public relations cooperate closely to help improve an organization's long-term sustainability?

Literature surveyed for this paper provides a theoretical link between finance, marketing, and public relations. Campbell (2006) explores the factors that affect socially responsible corporate behavior on institutions. He develops some causal propositions specifying the institutional conditions under which firms are likely to act in socially responsible ways. Smith \& Wright (2004) showed that corporate financial performance (CFP) is affected by customer satisfaction in the sense that customer satisfaction may be a driver of financial performance by mediating the relationship between market performance and financial performance. Mittal, Anderson, Sayrak, \& Tadikamalla (2005) found a link between customer satisfaction and long-term financial performance, especially in organizations that have a dual emphasis on satisfaction and efficiency. They point out that managers should not only focus on customer satisfaction or efficiency alone. Al-Wugayan, Pleshko, \& Baqer (2008) point out that there is no strong link between customer satisfaction and market share, postulating that customers may switch to organizations with better reputations even when satisfied with their current organization. Morgan \& Rego (2009) suggest that marketing spending should be seen as an investment by accountants, and not as an expense, since there is a positive link between market share and cash flow, and consumer loyalty and Tobin's q (Tobin's q, developed by James Tobin (Tobin, 1969) measures the ratio between market value and replacement value of the same physical asset). 
This paper examines, for the first time, the link between corporate financial performance (CFP), corporate social responsibility, and customer satisfaction in order to answer our research question. We therefore hypothesize as follows:

Organizations that have satisfied customers, a strong financial balance sheet and which achieve and maintain socially responsible growth, may achieve long-term sustainability and will therefore be able to avoid future economic hardship, loss of reputation, and other negative effects.

\section{Background}

Orlitzky, Schmidt, and Rynes (2003) identify a number of theories and hypotheses that discuss the relationship between corporate social responsibility (CSR) and corporate financial performance (CFP). The main theories are 1) instrumental stakeholder theory, 2) stakeholder-agency theory, 3) good management theory, and 4) slack resources theory.

In discussing Instrumental Stakeholder Theory, Jones (1995) suggests a positive relationship between CSR and CFP. For its part, Stakeholder-Agency Theory argues that stakeholdermanagement relationships serve as monitoring mechanisms that prevent managers from diverting their attention from broad organizational financial goals (Hill \& Jones, 1992; Jones, 1995). Freeman \& Evan (1990) point out that high corporate performance results not only from the separate satisfaction of bilateral relationships as proposed by Hill \& Jones (1992), but also from the simultaneous coordination and prioritization of multilateral stakeholder interests.

Good Management Theory (Waddock \& Graves, 1997) proposes that high levels of investing time, money, and effort in CSR activities bolsters a company's competitive advantage by weighing and addressing the claims of various constituents in a fair and rational manner. A positive association between CSR and CFP is also proposed by Slack Resources Theory (Ullmann, 1995; Waddock \& Graves, 1997), but, in addition, proposes that prior high levels of CFP may provide the slack resources necessary to engage in the subsequent CSR.

Furthermore, empirical evidence on the relationship between CSR and CFP yields mixed results. A positive significant relationship between CSR on CFP is shown by Griffin \& Mahon (1997), Orlitzky et al. (2003), Derwall, Guenster, Bauer, \& Koedijk (2005), Beurden \& Gössling (2008), Peloza \& Papania (2008), McPeak \&Tooley (2008), and Callan \&Thomas (2009).

However, Hartman, Rubin, \& Dhanda (2007), Mittal, Sinha, \& Singh (2008), and Surroca \& Tribó (2008) indicate that achieving high levels of CSR activities does not result in a good CFP. Nelling \& Webb (2009) use a time series fixed effects panel data approach, and found that the relation between CSR and CFP is much weaker than the traditional cross-sectional approach. Brammer \& Millington (2008) found that extremely high/low CSR focus may produce higher financial performance, with extremely poor CSR firms doing best in the short run and extremely good CSR firms doing best over longer time horizons.

By investigating the relationship between CSR and CFP, Griffin \& Mahon (1997), and Orlitzky et al. (2003) show that accounting-based financial performance indicator performs better than market-based indicators. Derwall et al. (2005) found that socially responsible investing (SRI) produced superior Tobin's q and return on total assets (ROA). However, $T d$, 8(2), Dec. 2012, pp. 167-187. 
Gil-Estallo, Giner-de-la-Fuente, \& Griful-Miquela (2009) found a neutral relationship between a Spanish CSR firm with ROE and ROA.

In addition, Hall \& Rieck (1998), Little \& Little (2000), Brammer, Brooks, \& Pavelin (2006), Mittal et al. (2008), and Luo \& Bhattacharya (2006) have empirically examined the linkage between corporate social responsibility and firm value. Hall \& Rieck (1998) show that the announcement of corporate donations has a significant positive effect on stock price. indicate that corporate reputation for social responsibility explains additional variation in price earning ratios. Brammer, Brooks, \& Pavelin (2006) observe that poor financial reward offered by CSR firms is attributable to their good social performances in UK. Luo \& Bhattacharya (2006) show that CSR contributes positively to market value. Mittal et al. (2008) show that CSR firms generate significantly more economic value added and market added value than those non-CSR firms included in their study.

In Luo \& Bhattacharya (2006)'s study, customer satisfaction is defined as an overall evaluation based on customer's total purchase and consumption expenditure with a good or service over time. Luo \& Bhattacharya (2006) points out that at least three research streams point to the link between CSR and customer satisfaction, the first stream is institutional theory and stakeholder theory, Brown \& Dacin (1997), Sen \& Bhattacharya (2001), and Gurhan-Canli \& Batra (2004) show that CSR creates a favorable context that positively boosts consumer's evaluation of and attitude toward the firm. Moreover, Sen \& Bhattacharya (2001), Jayachandran, Sharma, Kaufman, \& Raman (2005), and Mithas, Krishnan, \& Fornell (2005a) relate CSR to customer satisfaction examines the anteceedents of customer satisfaction.

Gruca \& Rego (2005), Fornell (1992), and Mittal et al. (2005b) found that high customer satisfactering firms are able to achieve higher level of cash flows and less volatility (Anderson, Fornell, \& Mazvancheryl 2004, and Fornell, Mithas, Morgeson, \& Krishnan, 2006), thus leading to superor market value. In Luo \& Bhattacharya's 2006 study, CSR affect customer satisfaction, which in turn affects market value.

Therefore, according to literature reviewed on the topic so far, it seems as if there are links between CSR, CFP, and customer satisfaction. As we know, there are short-run and longrun goals for corporate financial performance, our paper wants to know, whether CSR and customer satisfaction affect short-run or long-run corporate financial performance. In other words, if marketing (CS), public relations and other related CSR activities (CSR), and finance (CFP) were to better coordinate their efforts, could the organization benefit in the long run?

\section{Data and methodology}

The data used in this report are drawn from three main sources: 1) Dow Jones Sustainability Index, 2) Customer Satisfaction Index, and 3) Financial Statements. Each is discussed in more detail below.

\section{Dow Jones Sustainability Index (DJSI)}

The DJSI United States Index, launched in 1999, is a family of indexes specifically measuring the sustainability of the 2500 largest companies listed on the Dow Jones. It comprises the leading companies in terms of sustainability from the US, and was first published on 23 September 2005. As of 23 September 2005, the DJSI United States included 93 companies. 
However, the DJSI World Index comprises more than 300 companies that represent the top $10 \%$ of the leading sustainability companies out of the biggest 2500 companies in the Dow Jones Global Total Stock Market Index. The DJSI World Index data released by the STOXX Limited and SAM Group was ranged from 2002 to 2008. There are a total of 217 companies included in the DJSI World Index dataset with full financial data from 2001 to 2008 .

\section{American Customer Satisfaction Index (ACSI)}

This report used the ACSI from the University of Michigan, which has data from 1994 and it has more than 200 companies and federal or local government agencies from 10 economic sectors, representing 43 industries. In the period from 2001 to 2008, there are 246 companies in the ACSI index. Industries and sectors are broadly representative of the U.S. economy serving American households. However, 38 companies originally registered in the non-US country, 39 companies lack of stock price or financial data since the companies are not public trading or the companies are held by private funds. These 77 companies that are either nonUS registration or lack of financial data are excluded from this analysis. The number of ACSI group companies analyzed in this research is 169 . When we compared the 169 companies included in ACSI with DJSI group companies, we found that 59 out of the 169 companies are also included in the DJSI groups.

\section{Financial Statement Data}

We used COMPUSTAT Database to obtain financial statement data. Stock market data are taken from Data stream database. Our research will merge all the data from these databases. and will focus on the time period 2001-2008.

The sampling groups are divided into three groups: Group 1 focuses on the DJSI groups only. Group 2 describes the relationship between financial performance and the ACSI index. In addition, group 3 deals with the total groups containing both DJSI rated companies and ACSI companies, resulting in a sampling number of 333 companies.

The sampling group 3 was further separated into four parts:

- High score on customer satisfaction and in the Social Responsibility Index.

- High score on customer satisfaction and out of the Social Responsibility Index.

- Low score on customer satisfaction and in the Social Responsibility Index.

- Low score on customer satisfaction and out of the Social Responsibility Index.

\section{Panel Data Approach}

Our data has the cross-industry time series property, a panel data linear regression model is therefore considered as follows: 
$y_{i t}=\alpha_{i t}+\beta \times x_{i t}+\varepsilon_{i t}$

where

$i$ ( cross $-\sec$ tional effect $)=1 \sim N$, representing the number of firms

$t$ ( time - series effect $)=1 \sim T$, representing the number of times

$\varepsilon_{i t}=u_{i}+v_{i t}$

$u_{i} \sim$ iid with mean 0 , and variance $\sigma_{u}^{2}$,

$v_{i t} \sim$ iid with mean 0 , and variance $\sigma_{v}^{2}$.

If all firms have the same intercept, then $\alpha_{i t}=\alpha$, the ordinary least squared approach is an appropriate regression model. However, different companies, in practice, may represent different alpha since alpha indicates company's progress factor. Therefore, the fixed effect and random effect panel data approach will be conducted in order to reveal the different progress factor of companies.

Under fixed effect panel data approach: $\alpha_{i t}=\alpha_{i}$

Under random effect panel data approach: $\alpha_{i t}=\alpha+v_{i}, v_{i} \sim$ iid $\left(0, \sigma_{v}^{2}\right)$

Before we conduct the panel data regression, an F test for fixed effect approach or LM test for random effect approach should be conducted first to see whether the fixed effect model or random effect model should be used in the panel regression.

\section{Panel Data Regression Models}

In order to know whether corporate social responsibility and financial performance are generally positively related across a wide variety of industries, we conducted the panel data approach to empirically test the relationship between CSR and CFP. As shown by Griffin \& Mahon (1997), and Orlitzky et al. (2003), accounting-based and market-based financial performance may perform differently on CSR firms, therefore, both accounting-based and market-based indicators are used in the empirical test. The independent variables include growth rate of sales $\left(\mathrm{SGR}_{\mathrm{t}}\right)$, growth rate of sales margin $\left(\mathrm{SPR}_{\mathrm{t}}\right)$, return on equity $\left(\mathrm{ROE}_{\mathrm{t}}\right)$, macroeconomic impact $\left(\mathrm{SP} 500_{\mathrm{t}}\right)$, and also a set of dummies to indicate the ACSI firms or DJSI firms.

\section{Growth Rate of Sales (SGR)}

If corporate social responsibility investing induces high financial performance, then the growth rate of sales will be improved after the disclosure of ACSI or DJSI groups. Growth rate of sales is defined as:

$$
S G R_{t}=\frac{\text { Sales }_{t}-\text { Sales }_{t-1}}{\text { Sales }_{t-1}}
$$


Growth Rate of Sales Margin (SPR)

High financial performance under CSR investing may be evidenced by the high level of growth rate of sales margin. SPR is defined as $S P R_{t}=\frac{E B I T_{t}}{\text { Sales }_{t}}$, where EBIT (Earnings Before Interest and Tax) can be thought of as the operating profit margin.

Return on Equity (ROE)

$R O E_{t}=\frac{E B I T_{t}}{\text { Outs tanding shares of equity }}$, once again, the net income is replaced by EBIT in order to exclude the non-operating profits and losses.

Macroeconomic impact (SP500)

Since macroeconomic situations might influence firm's financial performance. We use the Standard and Poor's 500 index return as the proxy for macroeconomic growth. S\&P 500 index return is defined as the geometric average return of S\&P 500 index during the sample year.

\section{Dummy for firms in DJSI groups or in high ACSI groups}

If corporate social performance and financial performance are positively related, firm in DJSI groups or in high ACSI groups may produce better performance than non-group firms. Therefore, we will introduce three types of dummies to indicate the firm status.

$D_{A C S I_{t-i}}$ and $D_{D J S I_{t-i}}$ indicate that a firm is included in high ACSI group at date $\mathrm{t}-\mathrm{i}$, and in DJSI group at date t-i, respectively. $D_{A C S I_{t-i}, D J S I_{t-i}}$ denotes that a firm is both included in the high ACSI group and DJSI group at date $\mathrm{t}-\mathrm{i}$.

Our panel data regression model is divided into three parts. In the first part we use only the DJSI sample to test the DJSI impact on firm's financial performance. In the second part of regression, we study the impact of ACSI samples on firm's financial performance. In the final part of regression, we study the cross effect of ACSI and DJSI samples. We will briefly introduce the three regression models.

Those firms with an ACSI score higher than the average score of all ACSI firms will be denoted as high CSR firms. Those firms with an ACSI score lower than the average score will be denoted as low CSR firms. According to Instrumental Stakeholder Theory (Jones, 1995), high corporate social responsibility firms will perform well financially, however, Slack Resources Theory (Ullmann, 1985; Waddock, \& Graves, 1997) proposes that current high levels of corporate financial performance may be caused by prior CSR investment, therefore, we would like to know whether current investment, or whether prior investment in CSR will result in current high levels of corporate financial performance.

Regression 1 : Whether or not DJSI group firms perform better?

Financial Indicators $s_{t}$

$=$ Cons $\tan t+S P 500_{t}+S P R_{t}+S G R_{t}+$ Financial Indicators $_{t-1}+D_{D_{D S I_{t}}}+D_{D_{D S I_{t-1}}}+D_{D_{D S I_{t-2}}}+\varepsilon_{t}$ where

Financial Indicators include CFGR, ROE, SGR, and ISR 


$$
C F G R_{t}(\text { Cash flow growth rate })=\frac{\text { Operating Cash Flow }{ }_{t}-\text { Operating Cash Flow }_{t-1}}{\text { Operating Cash Flow }_{t-1}}
$$

$\mathrm{CFGR}_{\mathrm{t}}$ represents the growth rate of firm's operating cash flows. Operating cash flow is calculated as EBIT + Depreciation - Tax. $\mathrm{ROE}_{\mathrm{t}}$ represents firm's profitability in investing in DJSI firms. SGR $\mathrm{t}_{\mathrm{t}}$ represents the managerial ability in marketing.

$$
\text { daily stock return }=\frac{\text { Stock }_{\text {price }}-\text { Stock }_{\text {price }}{ }_{t-1}}{{\text { Stock } \text { price }_{t-1}}}
$$

ISR $\mathrm{t}_{\mathrm{t}}$ represents the DJSI impact on stock price, $\mathrm{ISR}_{\mathrm{t}}$ is defined as the average return of daily stock returns during the sampling year.

$$
I S R_{t}(\text { Individual stock return })=\frac{\sum_{i=1}^{N} \text { daily stock return }{ }_{t}}{\text { No. of days in yeart }}
$$

Regression 2: Whether or not high ACSI group firms perform better?

Financial Indicators

$=$ Cons $\tan t+S P 500_{t}+S P R_{t}+S G R_{t}+$ Financial Indicators $_{t-1}+D_{\text {ACSI }_{t}}+D_{A C S I_{t-1}}+D_{A C S I_{t-2}}+\varepsilon_{t}$ where

Financial Indicators include CFGR, ROE, SGR, and ISR

Regression 3: Whether or not Both in ACSI group and DJSI group firms perform better?

Financial Indicators

$$
\begin{aligned}
& =\text { Cons } \tan t+S P 500_{t}+S P R_{t}+S G R_{t}+\text { Financial Indicators }_{t-1}+D_{\text {ACSI }_{t}}+D_{\text {DJSI }_{t}}+D_{\text {ACSI }_{t}, \text { DSS }_{t}} \\
& +D_{A C S I_{t-1}}+D_{D J S I_{t-1}}+D_{A C S I_{t-1} D J S I_{t-1}}+D_{A C S I_{t-2}}+D_{D J S I_{t-2}}+D_{A C S I_{t-2}, D J S I_{t-2}}+\varepsilon_{t}
\end{aligned}
$$

where

Financial Indicators include CFGR, ROE, SGR, and ISR

There are 59 companies that belong to both ACSI group and DJSI group, we use the dummy $D_{A C S I, D J S I}$ to see whether firms belong to both ACSI group and DJSI group perform better than the other firms.

\section{Results}

Table 1 shows us the empirical result of the high CSR investing impact on the 169 ACSI firms' financial performance. As mentioned before, the financial performance indicators contain the macroeconomic dummy (return on S\&P 500 index, denoted by SP500t), the growth rate of sales margin (denoted by $\mathrm{SPR}_{\mathrm{t}}$ ) to represent the profitability of firm, the growth rate of sales (denoted by $\mathrm{SGR}_{\mathrm{t}}$ ) to represent the market shares of firm's operations, and the dummies which represent the firm's status where the firm falls in the high score of 
ACSI, or a low score of ACSI. If firm results in a high score of ACSI, then $D_{A C S I}$ will be 1 , otherwise $D_{A C S I}$ will be 0 .

Table 1: Does ACSI group firms result in a better financial performance? ${ }^{4}$

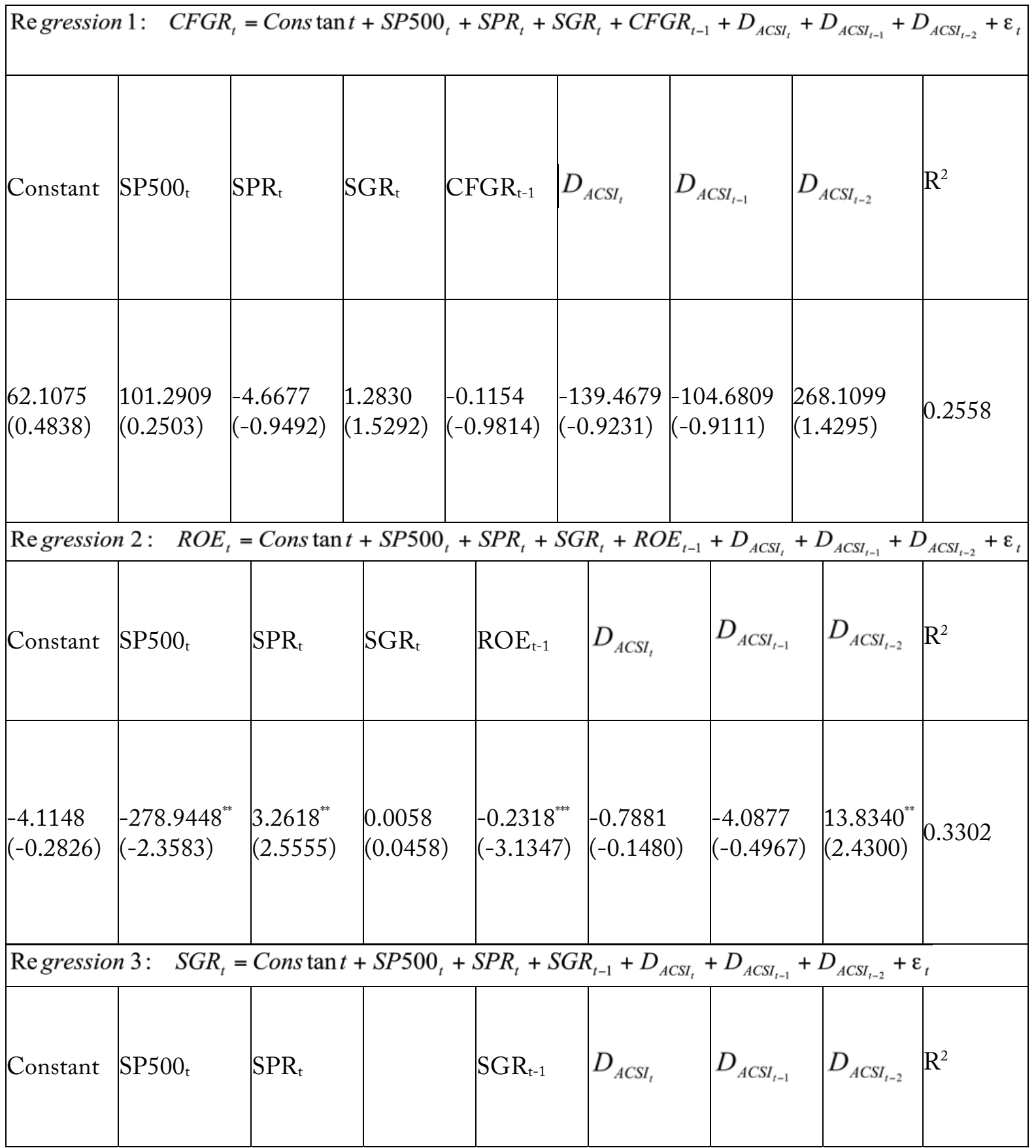

${ }^{4}$. Sampling data contains 169 firms. Data range is from 2002 to 2007. Parentheses are $t$ statistics. ${ }^{* * *},{ }^{* *}$, and ${ }^{*}$ represent significance at the $1 \%, 5 \%$, and $10 \%$ levels, respectively.

Td, 8(2), Dec. 2012, pp. 167-187. 


\begin{tabular}{|c|c|c|c|c|c|c|c|c|}
\hline $\begin{array}{l}9.6254^{*} \\
(1.6656)\end{array}$ & $\begin{array}{l}-8.7420 \\
(-0.1685)\end{array}$ & $\begin{array}{l}0.7359 \\
(3.6395)\end{array}$ & & $\begin{array}{l}-0.0292 \\
(-0.4967)\end{array}$ & $\begin{array}{l}-10.3134 \\
(-4.6344)\end{array}$ & $\begin{array}{l}-2.9737^{*} \\
(-1.7951)\end{array}$ & $\begin{array}{l}-5.2745 \\
(-2.1087)\end{array}$ & 0.4865 \\
\hline \multicolumn{9}{|c|}{ Re gression 4: $I S R_{t}=$ Cons $\tan t+S P 500_{t}+S P R_{t}+S G R_{t}+I S R_{t-1}+D_{A C S I_{t}}+D_{A C S I_{t-1}}+D_{A C S I_{t-2}}+\varepsilon_{t}$} \\
\hline Constant & $\mathrm{SP} 500_{\mathrm{t}}$ & $\mathrm{SPR}_{\mathrm{t}}$ & $\mathrm{SGR}_{\mathrm{t}}$ & $\mathrm{ISR}_{\mathrm{t}-1}$ & $D_{A C S I_{t}}$ & $D_{A C S I_{t-1}}$ & $D_{A C S I_{t-2}}$ & $\mathrm{R}^{2}$ \\
\hline $\begin{array}{l}2.3580^{\text {******** }} \\
(7.1663)\end{array}$ & $\begin{array}{l}0.057 \\
(0.0548)\end{array}$ & $\begin{array}{l}0.0316^{* * * * *} \\
(7.6312)\end{array}$ & $\mid \begin{array}{l}0.0035^{* * * *} \\
(5.3890)\end{array}$ & $\begin{array}{l}0.1917^{*} \\
(1.7877)\end{array}$ & $\begin{array}{l}-0.0201 \\
(-0.3057)\end{array}$ & $\begin{array}{l}0.0907 \\
(1.1347)\end{array}$ & $\begin{array}{l}-0.0234 \\
(-1.0596)\end{array}$ & 0.8218 \\
\hline
\end{tabular}

Regression 1 and regression 4 in Table 1 both show that high investment in CSR activities has no significant impact on the growth rate of operating cash flow (denoted by CFGR $\mathrm{t}_{\mathrm{t}}$ ) and individual stock return. However, if we look at regression 2 and 3, the empirical result shows that the high investment in CSR activities two periods ahead is positively significantly correlated with corporate current $\mathrm{ROE}_{\mathrm{t}}$ at $5 \%$ significant level, furthermore, current, 1 period prior, and 2 period prior CSR investment is significantly negatively correlated with current market share of the firm at 1\%,10\%, and 5\% significant level, respectively. Therefore, our results show that investment in CSR activities have a negative impact on firm's short-run and long-run market share. However, investments in CSR activities yield a positive impact on firm's long-run return on equity. Using $\mathrm{ROE}_{\mathrm{t}}$ as accounting-based financial performance indicator, our results support the instrumental stakeholder theory and the slack resources theory.

Using the information in Table 2, we can analyze whether DJSI firms outperform other firms. Regressions 1, 2, and 3 in Table 2 show that DJSI firms do not have significant high level of firm's growth rate of operating cash flow $\left(\mathrm{CFGR}_{t}\right), \mathrm{ROE}_{\mathrm{t}}$, and growth rate of market shares $\left(\mathrm{SGR}_{\mathrm{t}}\right)$. Leading sustainability firms do not perform well in stock price which is also supported by Lee \& Faff (2009). Regression 4 in Table 2 shows that being a leading sustainability firm is significantly positively related to firm's individual stock return. High investment in CSR activities (leading sustainability firms in this paper) is positively related to individual firm's stock return, which is also shown by Hall \& Rieck (1997) and Little \& Little (2000). 
Table 2: Does DJSI group firms result in a better financial performance? ${ }^{5}$

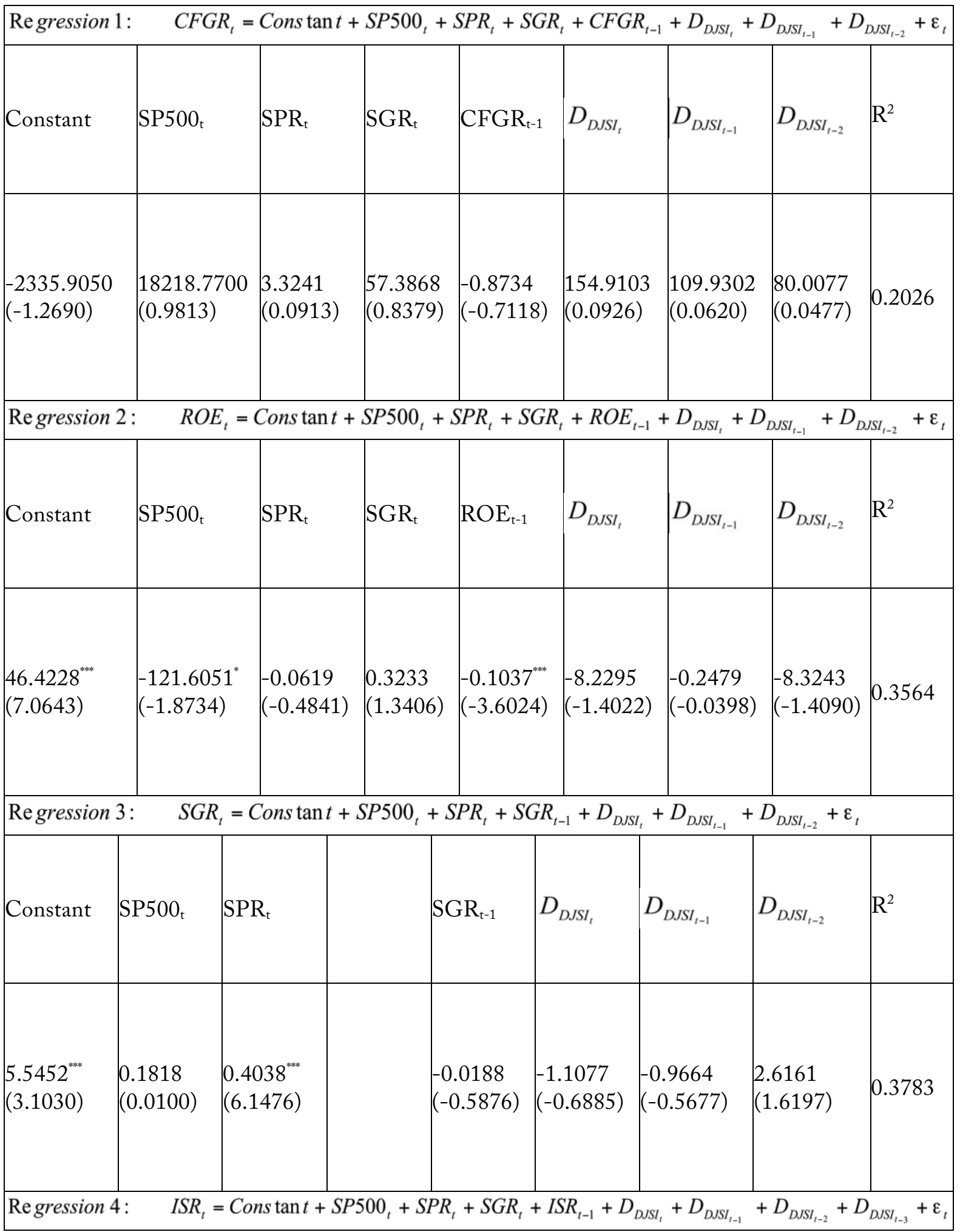

5 Sampling data contains 217 firms. Data range is from 2002 to 2007. Parentheses are t statistics. The ${ }^{* * *},{ }^{* *}$, and ${ }^{*}$ represent significance at the $1 \%, 5 \%$, and $10 \%$ levels, respectively. Td, 8(2), Dec. 2012, pp. 167-187. 


\begin{tabular}{|c|c|c|c|c|c|c|c|c|}
\hline Constant & $\mathrm{SP} 500_{\mathrm{t}}$ & $\mathrm{SPR}_{\mathrm{t}}$ & $\mathrm{SGR}_{\mathrm{t}}$ & $\mathrm{ISR}_{\mathrm{t}-1}$ & $D_{D_{D J I}}$ & $D_{D J S I_{t-1}}$ & $D_{D J S I_{t-2}}$ & $\mathrm{R}^{2}$ \\
\hline $\begin{array}{l}2.1568^{* * * * *} \\
(16.8393)\end{array}$ & $\begin{array}{l}1.3193^{* * * * *} \\
(3.8316)\end{array}$ & $\begin{array}{l}0.0025^{2 *} \\
(4.0586)\end{array}$ & $\mid \begin{array}{l}0.0032^{\text {******* }} \\
(2.7026)\end{array}$ & $\begin{array}{l}0.3708^{* a t} \\
(10.8236)\end{array}$ & $\begin{array}{l}0.0730^{* *} \\
(2.5662)\end{array}$ & $\begin{array}{l}0.0345 \\
(1.1505)\end{array}$ & $\begin{array}{l}-0.0014 \\
(-0.0494)\end{array}$ & 0.8708 \\
\hline
\end{tabular}

Prior researches have focused on either CSR investment (high ACSI score) or leading sustainability firms (DJSI firm). We would like to know whether firms with a high ACSI score and also be recorded as DJSI firm outperform other firms? Table 3 shows the panel lease squared result for all 333 companies in the DJSI groups or with ACSI scores. Regressions 1 and 2 of Table 3 Panel A show that, prior 2-period investment in CSR activities significantly positively related to firm's cash flow and $\mathrm{ROE}_{\mathrm{t}}$ at $1 \%$ level. Regressions 1 and 4 show that prior 3-period CSR investment significantly negatively related to firm's cash flow and stock price. Looking at the CSR investment on firm's operating cash flow $\left(\mathrm{CFGR}_{\mathrm{t}}\right)$ and its market shares $\left(\mathrm{SGR}_{\mathrm{t}}\right)$, current CSR activities have significantly negatively impact on short run performance. Therefore, our result in Table 3 Panel A shows (suggests?) that investment in CSR activities deteriorate firm's current financial performance, however, subsequently, a superior long run financial performance may be realized when the corporate system takes more interest in CSR activities.

Table 3 Panel A: Does ACSI group firms result in a better financial performance? ${ }^{6}$

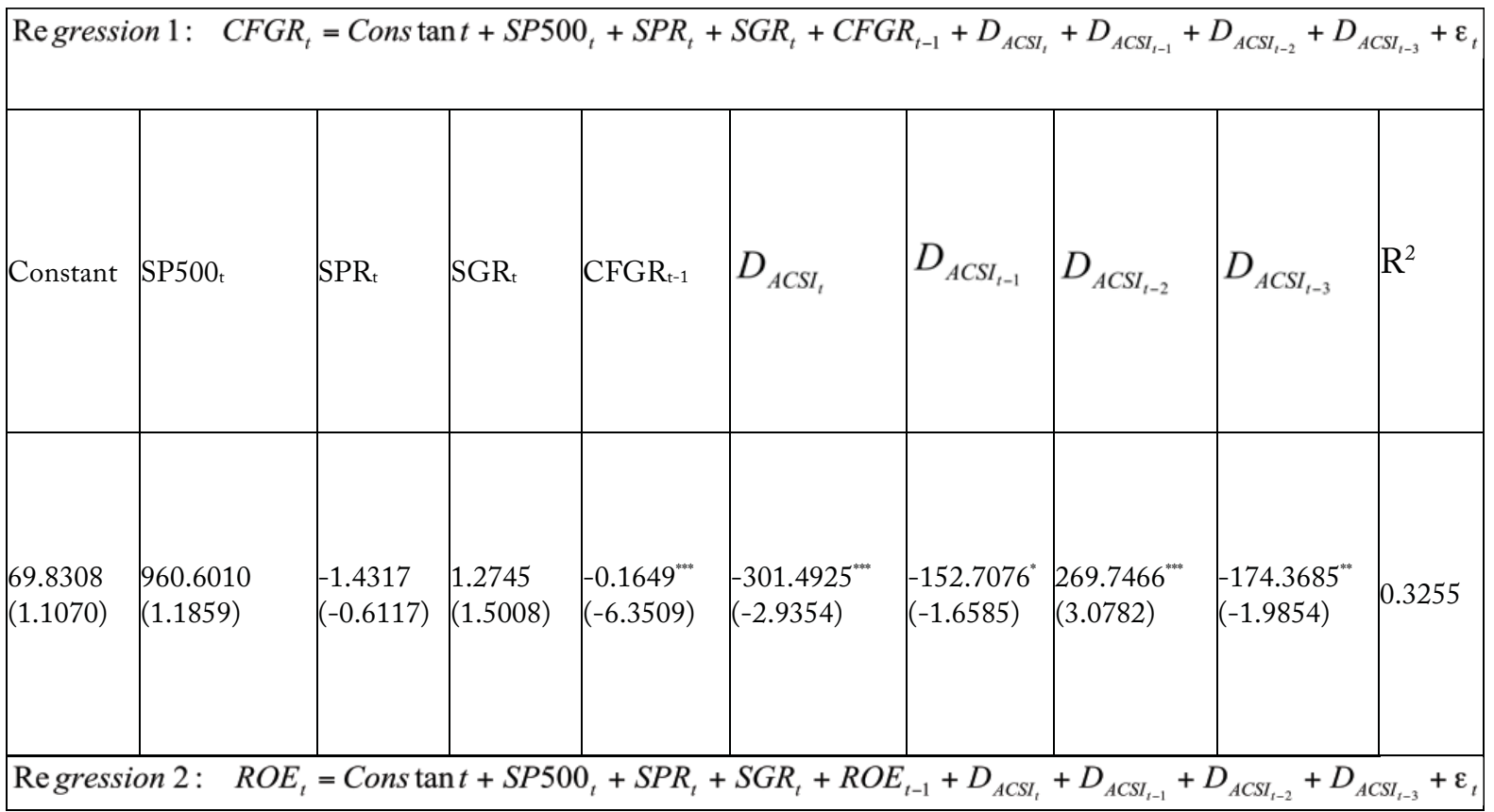

${ }^{6}$. Sampling data contains 333 firms. Data range is from 2002 to 2007. Parentheses are $t$ statistics. ${ }^{* * *}, * *$, and ${ }^{*}$ represent significance at the $1 \%, 5 \%$, and $10 \%$ levels, respectively. 


\begin{tabular}{|c|c|c|c|c|c|c|c|c|c|}
\hline Constant & SP500 & $\mathrm{SPR}_{\mathrm{t}}$ & $\mathrm{SGR}_{\mathrm{t}}$ & $\mathrm{ROE}_{\mathrm{t}-1}$ & $D_{A C S I_{t}}$ & $D_{A C S I_{t-1}}$ & $D_{A C S I_{t-2}}$ & $D_{A C S I_{t-3}}$ & $\mathrm{R}^{2}$ \\
\hline $\begin{array}{l}24.19377^{* *+} \\
(2.9037)\end{array}$ & $\begin{array}{l}-405.9365 \\
(-2.8603)\end{array}$ & $\begin{array}{l}0.9305^{* * *} \\
(4.3834)\end{array}$ & $\begin{array}{l}0.0175 \\
(0.3744)\end{array}$ & $\begin{array}{l}-0.1391 \\
(-1.0463)\end{array}$ & $\begin{array}{l}9.9930 \\
(1.3459)\end{array}$ & $\begin{array}{l}11.3712 \\
(1.1739)\end{array}$ & $\begin{array}{l}12.2629^{n+*} \\
(3.5397)\end{array}$ & $\begin{array}{l}15.0824 \\
(1.2069)\end{array}$ & 0.3394 \\
\hline \multicolumn{10}{|c|}{ Regression 3: $S G R_{t}=$ Cons tan $t+S P 500_{t}+S P R_{t}+S G R_{t-1}+D_{A C S I_{t}}+D_{A C S I_{t-1}}+D_{A C S I_{t-2}}+D_{A C S I_{t-3}}+\varepsilon_{t}$} \\
\hline Constant & $\mathrm{SP} 500_{\mathrm{t}}$ & $\mathrm{SPR}_{\mathrm{t}}$ & & $\mathrm{SGR}_{\mathrm{t}-1}$ & $D_{A C S I_{t}}$ & $D_{A C S I_{t-1}}$ & $D_{A C S I_{t-2}}$ & $D_{A C S I_{t-3}}$ & $\mathrm{R}^{2}$ \\
\hline $\begin{array}{l}8.6384 \\
(1.5422)\end{array}$ & $\begin{array}{l}54.4062 \\
(0.6989)\end{array}$ & $\begin{array}{l}0.4586^{* *} \\
(2.5339)\end{array}$ & & $\begin{array}{l}-0.1248 \\
(-0.9927)\end{array}$ & $\begin{array}{l}-8.3458^{* * *} \\
(-3.4718)\end{array}$ & $\begin{array}{l}-2.5874 \\
(-0.7800)\end{array}$ & $\begin{array}{l}-2.9770 \\
(-1.3824)\end{array}$ & $\begin{array}{l}-4.0351^{*} \\
(-1.9044)\end{array}$ & 0.4519 \\
\hline \multicolumn{10}{|c|}{ Regression 4: $I S R_{t}=$ Cons $\tan t+S P 500_{t}+S P R_{t}+S G R_{t}+I S R_{t-1}+D_{A C S I_{t}}+D_{A C S I_{t-1}}+D_{A C S I_{t-2}}+D_{A C S I_{t-3}}+\varepsilon_{t}$} \\
\hline Constant & $\mathrm{SP} 500_{\mathrm{t}}$ & $\mathrm{SPR}_{\mathrm{t}}$ & $\mathrm{SGR}_{\mathrm{t}}$ & $\mathrm{ISR}_{\mathrm{t}-1}$ & $D_{A C S I_{t}}$ & $D_{A C S I_{t-1}}$ & $D_{A C S I_{t-2}}$ & $D_{A C S I_{t-3}}$ & $\mathrm{R}^{2}$ \\
\hline \begin{tabular}{|l}
$2.61122^{* *}$ \\
$(3.2397)$
\end{tabular} & $\begin{array}{l}2.7417^{m+*} \\
(8.6037)\end{array}$ & $\begin{array}{l}0.0113^{* * *} \\
(7.7920)\end{array}$ & $\begin{array}{l}0.0026^{* * * *} \\
(5.2764)\end{array}$ & $\begin{array}{l}0.1965 \\
(0.8456)\end{array}$ & $\begin{array}{l}0.1202 \\
(1.4915)\end{array}$ & $\begin{array}{l}0.0789 \\
(1.2143)\end{array}$ & $\begin{array}{l}-0.0061 \\
(-0.2114)\end{array}$ & $\begin{array}{l}-0.0371^{* *} \\
(-3.2017)\end{array}$ & 0.8701 \\
\hline
\end{tabular}

Our result in Table 3 Panel B is mixed. Regression 2 shows that the current and prior 2 DJSI impact and $\mathrm{ROE}$ is significantly negatively related at $5 \%$ significant level, while the prior 1 DJSI impact has significantly positive effect on current ROE at $1 \%$ significant level. Moreover, Regression 3 of Table 3 Panel B also shows a mixed result regarding the impacts of DJSI on the growth rate of sales $\left(\mathrm{SGR}_{\mathrm{t}}\right)$. Impacts of Prior 1 period and prior 3 period DJSIs on SGR is significantly negatively related at $10 \%$ significant level. However, the current and prior 2 DJSI grouping has significantly positive impact on the growth rate of sales. Regression 4 shows that DJSI impact is significantly positively related to firm's stock return. In short, whether DJSI grouping has a significantly impact on accounting-based 
financial performance is not concluded, however, DJSI grouping firms outperform others on their stock returns.

Table 3 Panel B: Does DJSI group firms result in a better financial performance? ${ }^{7}$

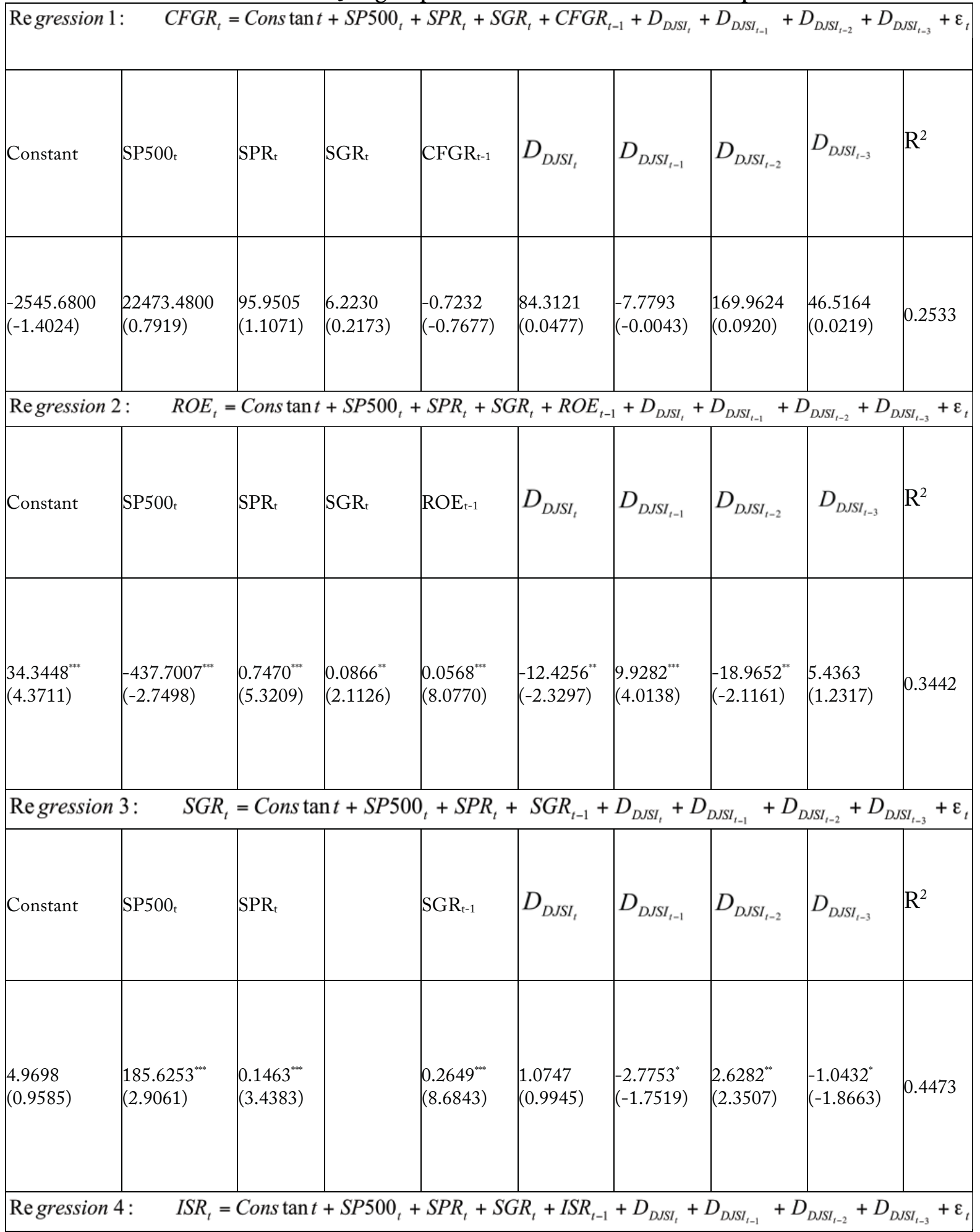

7. Sampling data contains 333 firms. Data range is from 2002 to 2007. Parentheses are $t$ statistics. ${ }^{* * *},{ }^{* *}$, and ${ }^{*}$ represent significance at the $1 \%, 5 \%$, and $10 \%$ levels, respectively. 


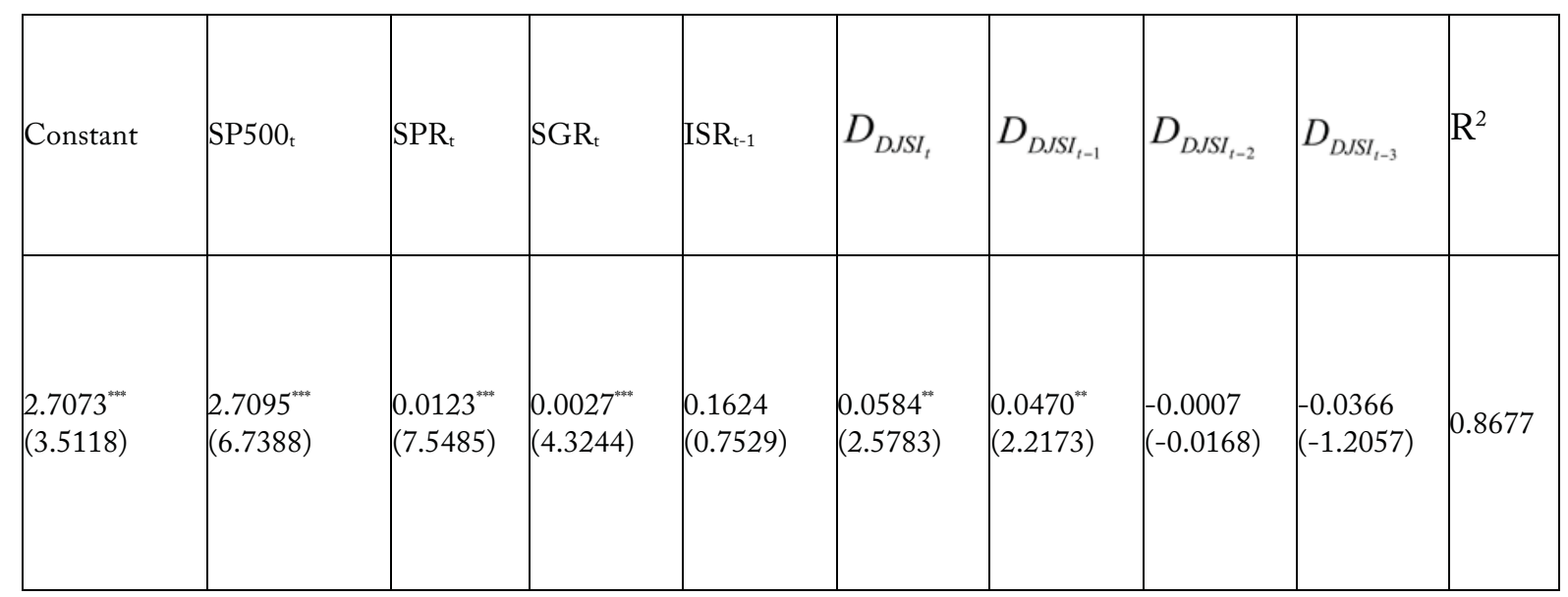

On Table 3 Panel $\mathrm{C}$ we will present the result that whether high level in ACSI and DJSI grouping will outperform others. The cross effect of high ACSI score and DJSI grouping is represented by ${ }_{A C S I, D J S I}$. In regressions 3 and 4, DJSI grouping firms with high ACSI score have significantly positive impact on $\mathrm{SGR}_{\mathrm{t}}$ at a $5 \%$ level, and significantly negative impact on ISR $_{\mathrm{t}}$ at a $10 \%$ level. In Regression 1, high level in ACSI will result in a significantly low level and high level of cash flow growth in the short run and long run at a $1 \%$ level, respectively. In Regression 3 and 4, high level in ACSI will result in a significantly low level of $\mathrm{SGR}_{\mathrm{t}}$ in the both short run and long run. Moreover, the DJSI grouping produces significantly negative impact on growth rate of sales and individual stock price. However, the DJSI impact on $\mathrm{ROE}_{\mathrm{t}}$ is still mixed, which means short run and long run effects of DJSI grouping on ROE is not conclusive. We conclude that DJSI grouping firm with high ACSI score produce negative long-run impact on stock price, and positive long-run impact on growth rate of cash flows.

Table 3 Panel C: Does both ACSI and DJSI group firms result in a better financial performance? ${ }^{8}$

\begin{tabular}{|c|c|c|c|c|c|c|c|c|c|}
\hline \multicolumn{10}{|c|}{ 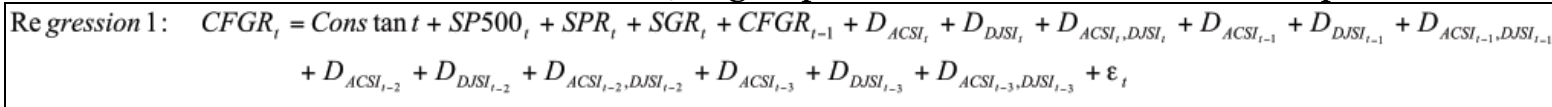 } \\
\hline Constant & $\mathrm{SP} 500_{\mathrm{t}}$ & $\mathrm{SPR}_{\mathrm{t}}$ & $\mathrm{SGR}_{\mathrm{t}}$ & CFGR $_{\mathrm{t}-1}$ & $\mathrm{D}_{\mathrm{ACSI}}$ & D DJSIt & $\mathrm{D}_{\mathrm{ACSI} i \mathrm{DJSII}}$ & $\mathrm{D}_{\text {ACSIt-1 }}$ & $\mathrm{D}_{\text {DJSIt-1 }}$ \\
\hline & $C$ & $+D$ & $D_{D J S I_{t}}$ & 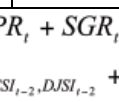 & ${ }_{-3}+$ & $\begin{array}{l}+D_{D J S I_{t}} \\
D_{A C S I_{t-3}, D}\end{array}$ & $\begin{array}{l}I_{t}, D S S I_{t}+ \\
\varepsilon_{t}\end{array}$ & $+D_{D J S I_{t-\text { }}}$ & \\
\hline
\end{tabular}

8. Sampling data contains 333 firms. Data range is from 2002 to 2007. Parentheses are $t$ statistics. ${ }^{* * *},{ }^{* *}$, and ${ }^{*}$ represent significance at the $1 \%, 5 \%$, and $10 \%$ levels, respectively.

Td, 8(2), Dec. 2012, pp. 167-187. 


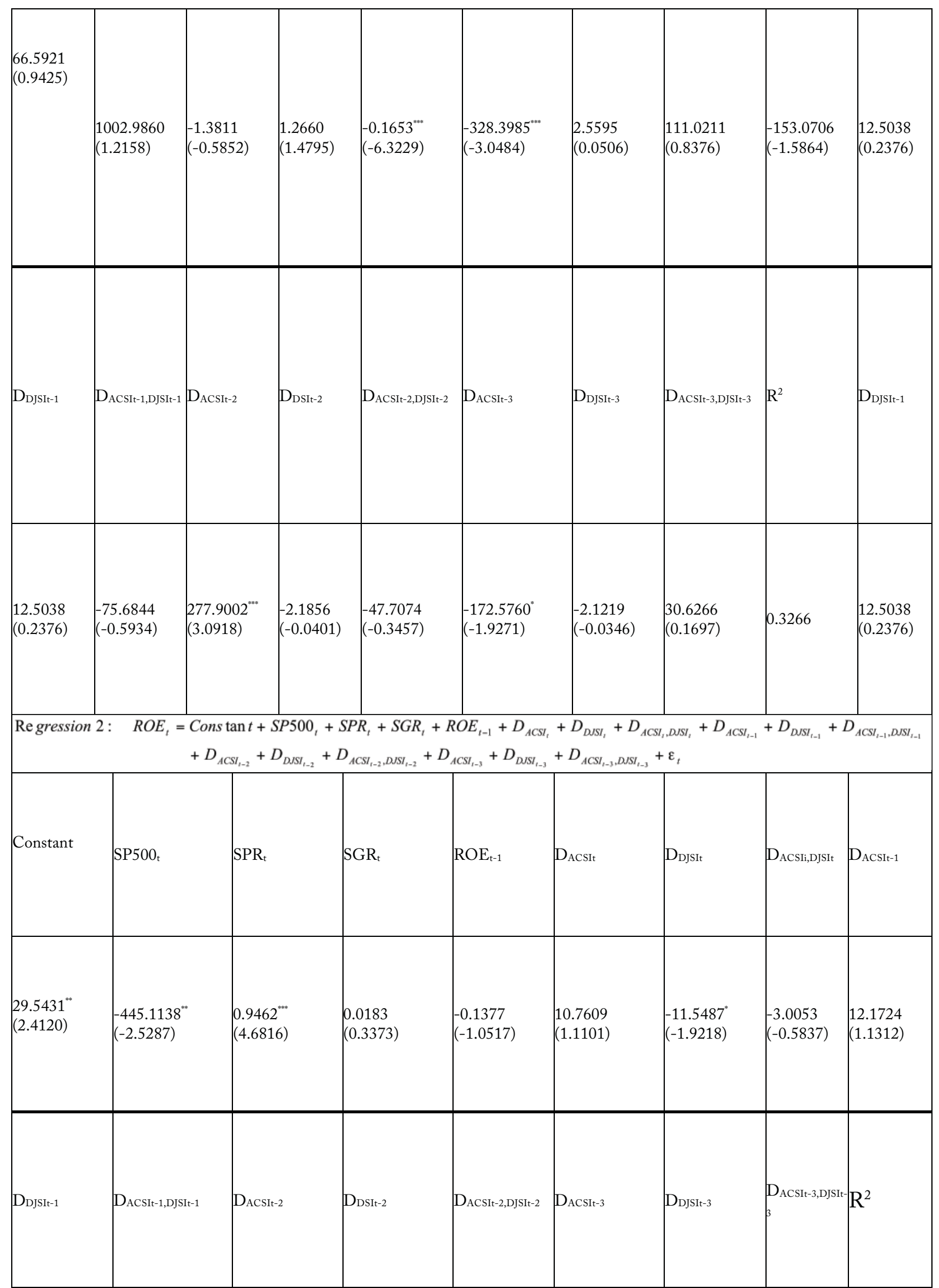




\begin{tabular}{|c|c|c|c|c|c|c|c|c|}
\hline $\begin{array}{l}8.0631^{* n+} \\
(3.8685)\end{array}$ & $\begin{array}{l}3.4029 \\
(1.0559)\end{array}$ & $\begin{array}{l}11.5306^{2 n} \\
(3.0207)\end{array}$ & $\begin{array}{l}-18.6818^{* *} \\
(-2.0949)\end{array}$ & $\begin{array}{l}4.3374 \\
(0.8868)\end{array}$ & $\begin{array}{l}16.2726 \\
(1.3134)\end{array}$ & $\begin{array}{l}6.0478 \\
(1.2073)\end{array}$ & $\begin{array}{l}8.2513 \\
(1.0060)\end{array}$ & 0.3441 \\
\hline \multicolumn{9}{|c|}{ Re gression 3: } \\
\hline Constant & $\mathrm{SP} 500_{\mathrm{t}}$ & $\mathrm{SPR}_{\mathrm{t}}$ & & $\mathrm{SGR}_{\mathrm{t}-1}$ & $\mathrm{D}_{\text {ACSIt }}$ & $\mathrm{D}_{\text {DJSIt }}$ & D ACSIi,DJSIt & $\mathrm{D}_{\text {ACSIt }-1}$ \\
\hline $\begin{array}{l}8.1916 \\
(1.5198)\end{array}$ & $\begin{array}{l}58.1811 \\
(0.7496)\end{array}$ & $\begin{array}{l}0.4657^{* * * *} \\
(2.7095)\end{array}$ & & $\begin{array}{l}-0.1269 \\
(-1.0215)\end{array}$ & $\begin{array}{l}-9.5537^{+a n t} \\
(-3.0248)\end{array}$ & $\begin{array}{l}-1.2484 \\
(-0.8118)\end{array}$ & $\begin{array}{l}3.7328 \\
(1.0854)\end{array}$ & $\begin{array}{l}-2.3903 \\
(-0.5885)\end{array}$ \\
\hline D DJSIt-1 & D ACSIt-1,DJSIt-1 & $\mathrm{D}_{\text {ACSIt-2 }}$ & D DSIt-2 & D ACSIt-2,DJSIt-2 & $\mathrm{D}_{\text {ACSIt-3 }}$ & DDJSIt-3 & $\begin{array}{l}\mathrm{D}_{\text {ACSIt- }} \\
\text { 3,DJSIt-3 }\end{array}$ & $\mathrm{R}^{2}$ \\
\hline $\begin{array}{l}-1.6772 \\
(-0.8565)\end{array}$ & $\begin{array}{l}-2.1683 \\
(-0.5472)\end{array}$ & $\begin{array}{l}-2.8611 \\
(-1.3042)\end{array}$ & $\begin{array}{l}1.8576 \\
(0.8155)\end{array}$ & $\begin{array}{l}1.1804 \\
(0.8984)\end{array}$ & $\begin{array}{l}-4.7016^{*} \\
(-1.8536)\end{array}$ & $\begin{array}{l}3.0002^{* *} \\
(2.1799)\end{array}$ & $\begin{array}{l}4.6479^{* *} \\
(2.0672)\end{array}$ & 0.4558 \\
\hline \multicolumn{9}{|c|}{ 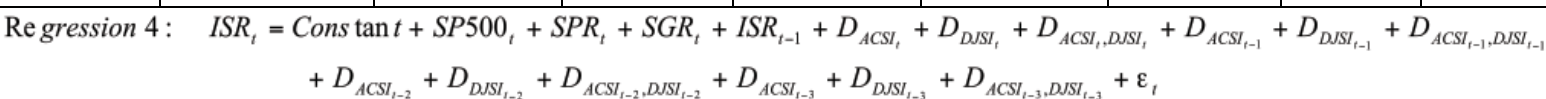 } \\
\hline Constant & $\mathrm{SP} 500_{\mathrm{t}}$ & $\mathrm{SPR}_{\mathrm{t}}$ & $\mathrm{SGR}_{\mathrm{t}}$ & $\mathrm{CFGR}_{\mathrm{t}-1}$ & $\mathrm{D}_{\mathrm{ACSIt}}$ & $\mathrm{D}_{\text {DJSIt }}$ & $\mathrm{D}_{\text {ACSIi,DJSIt }}$ & $\mathrm{D}_{\text {ACSIt }-1}$ \\
\hline $\begin{array}{l}2.6238^{* * * *} \\
(3.3080)\end{array}$ & $\begin{array}{l}2.7636^{* * * *} \\
(8.9811)\end{array}$ & $\begin{array}{l}0.0115^{* * *} \\
(7.1954)\end{array}$ & $\begin{array}{l}0.0028^{* * * * *} \\
(4.9057)\end{array}$ & $\begin{array}{l}0.1824 \\
(0.7937)\end{array}$ & $\begin{array}{l}0.1385 \\
(1.5203)\end{array}$ & $\begin{array}{l}0.0661^{* * * *+} \\
(2.9281)\end{array}$ & $\begin{array}{l}-0.0791 \\
(-1.4193)\end{array}$ & $\begin{array}{l}0.0900 \\
(1.2380)\end{array}$ \\
\hline $\mathrm{D}_{\text {DJSIt-1 }}$ & $\mathrm{D}_{\mathrm{ACSIt}-1, \mathrm{DJSIt}-1}$ & $\mathrm{D}_{\text {ACSIt-2 }}$ & $\mathrm{D}_{\text {DSIt-2 }}$ & $\mathrm{D}_{\text {ACSIt-2,DJSIt-2 }}$ & $\mathrm{D}_{\mathrm{ACSI}-3}$ & $\mathrm{D}_{\text {DJSIt-3 }}$ & $\begin{array}{l}\mathrm{D}_{\text {ACSIt- }} \\
\text { 3,DISIt-3 }\end{array}$ & $\mathrm{R}^{2}$ \\
\hline
\end{tabular}




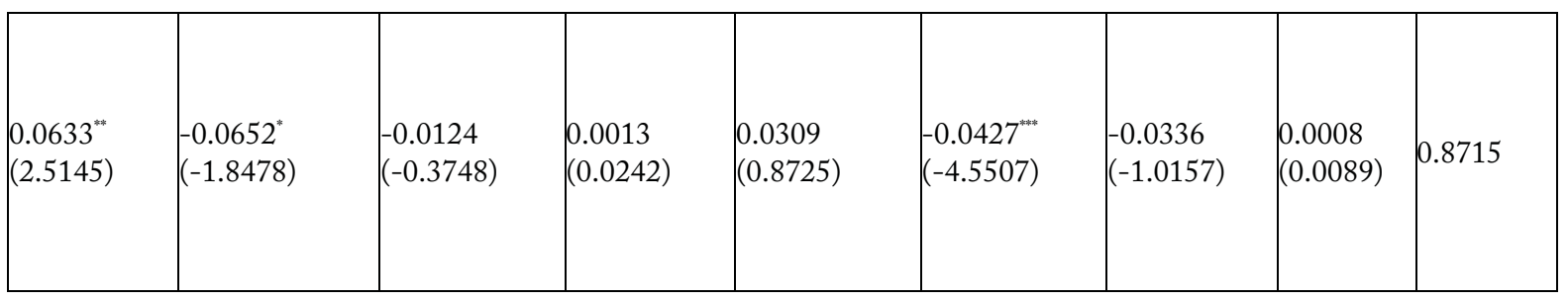

The main preliminary results from our exploratory study (based on a limited data set) are therefore as follows:

- CSR investment negatively affects short term stock price, but improves long term stock return.

- CSR investment results in long term superior financial performance.

- Customer satisfaction negatively affects short term stock prices, but positively affects cash flow growth rate.

The results tend to support the hypothesis that long-term sustainability is directly linked to high levels of CSR and high levels of customer satisfaction - two activities that have a negative impact on short term stock price, but which improves return on investment in the long run.

\section{Conclusion}

In this paper, we wanted to investigate whether investment in CSR will result in a high level of short-run or long-run financial performance. By reviewing the ACSI listed firms only, our results show that investments in CSR activities have a negative impact on firm's short-run and long-run market share, however, investments in CSR activities yield a positive impact on firm's long-run return on equity.

By asking whether the DJSI grouping indicate a high level of financial performance, our empirical findings show that being a leading sustainability firm is significantly positively related to firm's individual stock return. High investment in CSR activities (leading sustainability firms in this paper) is positively related to individual firm's stock return is also evidenced by Hall \& Rieck (1997) and Little \& Little (2000).

Finally, since prior research focuses on the CSR investment (high ACSI score) only or on the leading sustainability firm (DJSI firm) only, we wanted to know whether the firm with high ACSI score and also be recorded as DJSI firm may outperform others? Our panel lease squared result for the whole samples reveals that DJSI grouping firm with high level of ACSI activities produce negative long-run impact on stock price, and positive long-run impact on growth rate of cash flows.

Based on the empirical evidence presented in this paper, it seems logical for firms to investigate ways in which they can spend money, time, and effort in planning, coordinating and implementing CSR activities, since a positive correlation exists between CSR, customer satisfaction, and CFP. While shareholders may be dissatisfied at the initial downward movement in market share, they could take heart in realizing that their long term investments will improve. Moreover, spending on improved customer satisfaction may also have a positive effect on cash flow growth, but may negatively affect stock price. 
It is clear that using stock price alone as a measure of organizational success - chasing the short term profit - is not advisable in the long run, and a focused approach in designing business strategies to increase stock price may lead organizations to the brink of collapse in the long run. Organizations that aim to build sustainable business will therefore have to shift the focus away from a stock-price-only measure, and include measures taking cognizance of CSI and customer satisfaction.

It makes sense for organizations to take the longer-term view. The current economic crisis was in part caused by an increasingly short-term drive for quick profit. The question now remains - how can organizations ensure that they follow a prudent and integrated approach to designing and implementing CSR and customer satisfaction programs that will in fact contribute to a higher ROE. This could be grounds for further research.

\section{References}

Al-Wugayan, A., Pleshko, L.P., \& Baqer, S.M., An Investigation of the relationships among consumer satisfaction, loyalty, and market share in Kuwaiti loan services, Journal of Financial Services Marketing, Vol. 13, No. 2, pp. 95-106, 2008.

Anderson, E. W., Fornell, C., \& Mazvancheryl, S. K., Customer Satisfaction and Shareholder Value, Journal of Marketing, Vol. 68, pp. 172-185, 2004.

Beurden, P. V., \& Gössling, T., The Worth of Values - A Literature Review on the Relation Between Corporate Social and Financial Performance, Journal of Business Ethics, Vol. 82, No. 2, pp. 407-424, 2008.

Brammer, S., Brooks, C. \& Pavelin, S. Corporate social performance and stock returns: UK evidence from disaggregate measures. Financial Management. Vol. 35, No. 3, pp. 97116, 2006.

Brammer, S., \& Millington, A., Does it pay to be different? An Analysis of the Relationship between Corporate Social and Financial Performance, Strategic Management Journal, Vol. 29, No. 12, pp. 1325-1343, 2008.

Brown, T. J., \& Dacin, P. A., The Company and the Product: Corporate Associations and Consumer Product Responses, Journal of Marketing, Vol. 16, January, pp. 68-84, 1997.

Callan, S. J., \& Thomas, J. M., Corporate Financial Performance and Corporate Social Performance: an Update and Reinvestigation, Corporate Social Responsibility and Environmental Management, Vol. 16, No. 2, pp. 61-78, 2009.

Campbell, J. L., Institutional Analysis and the Paradox of Corporate Social Responsibility, The American Behavioral Scientist, Vol. 49, No. 7, pp. 925-938, 2006.

Derwall, J., Guenster, N., Bauer, R., \& Koedijk, K., The Eco-Efficiency Premium Puzzle. Financial Analyst Journal, Vol. 61, No. 2, pp. 51-63, 2005.

Fornell, C., A National Customer Satisfaction Barometer: the Swedish Experience, Journal of Marketing, Vol. 6, pp. 1-21, 1992.

Fornell, C., Mithas, S., Morgeson III, F. V., \& Krishnan, M. S., Customer Satisfaction and Stock Prices: High Return, Low Risk, Journal of Marketing, Vol. 70, pp. 3-14, 2006. 
Freeman, R. E., \& Evan, W. M., Corporate governance: A stakeholder interpretation, Journal of Behavioral Economics, Vol. 19, No. 4, pp. 337-359, 1990.

Gil-Estallo, M., Giner-de-la-Fuente, F., \& Griful-Miquela, C., Benchmarking Corporate Social Responsibility within Spanish Companies, Int Adv Econ Res, Vol. 15, pp. 2074-225, 2009.

Griffin, J. J., \& Mahon, J. F., The Corporate Social Performance and Corporate Financial Performance Debate: Twenty-Five Years of Incomparable Research, Business and Society, Vol. 36, No. 1, pp. 5-31, 1997.

Gruca, T.S., \& Rego, L. L., Customer Satisfaction, Cash Flow, and Shareholder Value, Journal of Marketing, Vol. 69, pp. 115-130, 2005.

Gurhan-Canli, Z, \& Batra, R, When Corporate Image Affects Product Evaluations: The Moderating Role of Perceived Risk, Journal of Marketing Research, Vol. 41, pp. 197205, 2004.

Hall, P. L., \& Rieck, R., The Effect of Positive Corporate Social Actions on Shareholder Wealth, Journal of Financial and Strategic Decision, Vol. 11, No. 2, pp. 83-89, 1998.

Hartman, L. P., Rubin, R. S., \& Dhanda, K. K., The Communication of Corporate Social Responsibility: United States and European Union Multinational Corporations, Journal of Business Ethics, Vol. 74, No. 4, pp. 373-389, 2007.

Hill, C W. L., and Jones, T. M., Stakeholder-agency theory, Journal of Management Studies, Vol. 29, pp. 131-154. 1992.

Jayachandran, S., Sharma, S., Kaufman, P., \& Raman, P., The Role of Relational Information Processes and Technology Use in Customer Relationship Management, Journal of Marketing, Vol. 69, pp. 177-192, 2005.

Jones, T. M., Instrumental stakeholder theory: A synthesis of ethics and economics, Academy of Management Review, Vol. 20, pp. 404-437, 1995.

Lee, D. D., \& Faff, R. W. Corporate Sustainability Performance and Idiosyncratic Risk: A Global Perspective, The Financial Review, Vol. 44, No. 2, pp. 213-256, 2009.

Little, P. L, \& Little, B.L., Do Perceptions of Corporate Social Responsibility Contribute to Explaining Difference in Corporate Price-Earning Ratios? A Research Note, Corporate Reputation Review, Vol. 3, No. 2, pp. 137-142, 2000.

Luo, X., \& Bhattacharya, C. B., Corporate Social Responsibility, Customer Satisfaction, and Market Value, Journal of Marketing, Vol. 70, No.4, pp. 1-18, 2006.

McPeak, C.,\& Tooley, N., Do Corporate Social Responsibility Leaders Perform Better Financially? Journal of Global Business Issues, Vol. 2, No.2, pp. 1-6, 2008.

Mithas, V., Krishnan, M. S., \& Fornell, C., Effects of Information Technology Investments on Customer Satisfaction Theory and Evidence, working paper, Ross School of Business, University of Michigan, 2005a.

Mittal, V., Anderson, E.W., Sayrak, A., \& Tadikamalla, P., Dual Emphasis and the Longterm Financial Impact of Customer Satisfaction, Marketing Science, Vol. 24, No. 4, pp. 544-555, 2005b. 
Mittal, R. K., Sinha, N., \& Singh, A., An Analysis of Linkage between Economic Value Added and Corporate Social Responsibility, Management Decision, Vol. 46, No. 9, pp. 1437-1443, 2008.

Morgan, N.A., \& Rego, L.L., Brand portfolio strategy and firm performance, Journal of Marketing, Vol. 73(January), pp. 59-47, 2009.

Nelling, E., \& Webb, E., Corporate Social Responsibility and Financial Performance: the "Virtuous Circle" Revisited, Revierw of Quantitative Finance and Accounting, Vol. 32, No. 2, pp. 197-209, 2009.

Orlitzky, M., Schmidt, F. L., \& Rynes, S. L., Corporate Social and Financial Performance: A Meta-Analysis, Organization Studies, Vol. 24, No. 3, pp. 403-441, 2003.

Peloza, J., \& Papania, L., The Missing Link between Corporate Social Responsibility and Financial Performance: Stakeholder Salience and Identification, Corporate Reputation Review, Vol. 11, No. 2, pp. 169-181, 2008.

Porter, M.E. \& Kramer, M.R., Strategy and society: the link between competitive advantage and corporate social responsibility, Harvard Business Review, Vol. 84, No. 12, pp. 7892, 2006.

Sen, S., \& Bhattacharya, C. B., Does Doing Good Always Leading to Doing Better? Consumer Reactions to Corporate Social Responsibility, Journal of Marketing Research, Vol. 38, pp. 225-244, 2001.

Smith, R.E., \& Wright, W.F., Determinants of Customer Loyalty and Financial Performance, Journal of Management Accounting Research, Vol. 16, pp. 183-205, 2004.

Surroca, J. \& Tribó, J. A., Managerial Entrenchment and Corporate Social Performance, Journal of Business Finance and Accounting, Vol. 35, No. 5/6, pp. 748-789, 2008.

Ullmann, A., Data in search of a theory: A critical examination of the relationship among social performance, social disclosure, and economic performance, Academy of Management Review, Vol. 10, pp. 540-577, 1985.

Waddock, S. A., and Graves, S. B., The corporate social performance- financial performance link, Strategic Management Journal, Vol. 18, pp. 303-319, 1997.

Wigley, S., Gauging consumers' responses to CSR activities: Does increased awareness make cents?, Public Relations Review, Vol. 34, pp. 306-308, 2009. 